\title{
Prediction of Mechanical Properties of Cold Rolled Steel Using Genetic Expression Programming
}

\author{
E. KANCA ${ }^{a, *}$, F. ÇAVDAR ${ }^{b}$ AND M.M. ERŞEN ${ }^{c}$ \\ ${ }^{a}$ İskenderun Technical University, Mechanical Engineering Department, Hatay, Turkey \\ ${ }^{b}$ İskenderun Technical University, Dörtyol Vocational School, Machinery Department, Hatay, Turkey \\ ${ }^{c}$ MMK Metalurji San. Tic. ve Liman İsletmeciligi A.S., Hatay, Turkey
}

\begin{abstract}
A new model was developed to predict the mechanical properties of St22 grade cold rolled deep drawing steel by gene expression programming. To obtain a dataset to find out the effect of reduction rate on the mechanical properties of cold rolled and galvanized steel sheet, an experimental program was constructed in the real production plant by keeping all other process parameters constant. The training and testing data sets of gene expression programming model were obtained from the test results. For gene expression programming model, mechanical properties (yield strength, ultimate tensile strength and elongation) before cold rolling, chemical composition, initial sheet thickness and reduction rate were used as independent input variables, while mechanical properties after cold rolling (yield strength, ultimate tensile strength and elongation) were used as dependent output variables. Before constructing the gene expression programming models for dependent variables, dataset was analyzed using the analysis of variance and statistically significant $(P \leq 0.1)$ independent parameters, i.e. initial sheet thickness, reduction rate, initial yield strength, initial tensile strength, elongation and Mn content were used in gene expression programming model. Different models were obtained for each dependent variable depending on the significant independent variables using the training dataset and accuracy of the best models was verified with testing data set. The predicted values were compared with experimental results and it was found that models are in good agreement with the experimentally obtained results.
\end{abstract}

DOI: 10.12693/APhysPolA.130.365

PACS/topics: 81.20.Hy, 81.05.U, 07.05.Mh, 81.40.Ef, 89.20.Bb

\section{Introduction}

Low carbon steel is the most widely used steel type due to its good weldability, high strength and high ductility [1]. It is well known that new microstructures might be created and new properties might be developed by heat treatment and processing of low carbon steel. Cold rolling reduces the grain size and increases the hardness of low carbon steel and annealing increases the toughness [1-3].

Low carbon steel has been studied continuously because in addition to chemical composition, processing parameters including hot, warm and cold forming, thermal processing parameters highly influence the microstructure and mechanical properties of low carbon steel [4-6]. Fast cooling after hot rolling has been reported to lead more pearlite and finer ferrite grain size that is more critical than finish rolling temperatures for low carbon cold heading steel [6]. Some attempts also have been performed to predict result of cold rolling of low carbon steel. Brahme et al. developed an artificial neural network model for the prediction of cold rolling textures of steels. In that study, fiber texture was predicted excellently by using fiber texture intensities, carbon content, carbide size and amount of rolling reduction [7].

There is a lack of studies on effect of cold rolling on mechanical properties of low carbon steel in the literature. In this study, products of an industrial plant producing galvanized sheets were used to develop a genetic expression programming model supported with analysis of variance. Yield strength, ultimate tensile strength, elongation, chemical composition and thickness of the materials before cold rolling and reduction rate are the input of the model to predict yield strength, final tensile strength and elongation of the final product (galvanized steel sheet).

\section{Experimental}

\subsection{Materials and equipment}

Material utilized in this study is obtained from a galvanized sheet production plant. Hot rolled sheets of St22 grade are used to produce galvanized sheets. Tensile tests were applied with respect to EN 10002 standard using Zwick Roell Z250 tensile testing apparatus.

\subsection{Experimental procedure}

St22 grade sheets with 1.5, 1.8 and $2.0 \mathrm{~mm}$ thickness were cold rolled with different reduction rates. Then, cold rolled sheet is annealed at $750^{\circ} \mathrm{C}$ before it is dipped into molten zinc bath at $460^{\circ} \mathrm{C}$. Yield strength, ultimate tensile strength and elongation is determined for each material before and after cold rolling. Mechanical properties (yield strength, tensile strength and elongation), chemical composition and initial thickness of the raw material, reduction ratio and mechanical properties of finished product are given in Table I. 
TABLE I

Properties of row material and finished products.

\begin{tabular}{|c|c|c|c|c|c|c|c|c|c|c|c|}
\hline \multirow[b]{2}{*}{ No } & \multirow[b]{2}{*}{$\begin{array}{c}T_{0} \\
{[\mathrm{~mm}]}\end{array}$} & \multirow[b]{2}{*}{$\begin{array}{c}\mathrm{R} \\
{[\%]}\end{array}$} & \multicolumn{3}{|c|}{ Mechanic propertie after cold rolling } & \multirow[b]{2}{*}{$\begin{array}{c}\mathrm{C} \\
{[\% 0]}\end{array}$} & \multirow[b]{2}{*}{$\left.\begin{array}{c}\mathrm{S} \\
{[\% \mathrm{o}]}\end{array}\right]$} & \multirow[b]{2}{*}{$\begin{array}{c}\text { Residue } \\
{[\% 0]}\end{array}$} & \multicolumn{3}{|c|}{ Mechanic properties before cold rolling } \\
\hline & & & $\begin{array}{c}\text { Yield } \\
\text { stress } \\
{[\mathrm{MPa}]}\end{array}$ & $\begin{array}{l}\text { Tensile } \\
\text { stress } \\
{[\mathrm{MPa}]}\end{array}$ & $\begin{array}{c}\text { Elongation } \\
{[\%]}\end{array}$ & & & & $\begin{array}{r}\text { Yield } \\
\text { stress } \\
{[\mathrm{MPa}]}\end{array}$ & $\begin{array}{l}\text { Tensile } \\
\text { stress } \\
{[\mathrm{MPa}]}\end{array}$ & $\begin{array}{c}\text { Elongation } \\
{[\%]}\end{array}$ \\
\hline 1 & 1.8 & 64 & 220 & 300 & 38 & 0.43 & 0.15 & 0.59 & 253 & 332 & 41.6 \\
\hline 2 & 1.8 & 64 & 223 & 302 & 38 & 0.43 & 0.15 & 0.59 & 253 & 332 & 41.6 \\
\hline 3 & 1.8 & 51 & 210 & 309 & 38 & 0.37 & 0.12 & 0.59 & 239 & 339 & 41.5 \\
\hline 4 & 2.0 & 77 & 225 & 310 & 34 & 0.32 & 0.09 & 0.54 & 251 & 339 & 38.3 \\
\hline 5 & 1.5 & 63 & 205 & 310 & 34 & 0.38 & 0.09 & 0.51 & 225 & 337 & 37.8 \\
\hline 6 & 1.5 & 62 & 210 & 285 & 34 & 0.29 & 0.05 & 0.46 & 237 & 315 & 37.6 \\
\hline 7 & 1.5 & 79 & 245 & 330 & 33 & 0.35 & 0.1 & 0.53 & 270 & 360 & 36.9 \\
\hline 8 & 1.5 & 63 & 226 & 340 & 33 & 0.36 & 0.08 & 0.39 & 256 & 367 & 36.8 \\
\hline 9 & 1.8 & 58 & 205 & 300 & 33 & 0.47 & 0.04 & 0.44 & 232 & 330 & 36.5 \\
\hline 10 & 1.5 & 63 & 210 & 310 & 32 & 0.37 & 0.09 & 0.4 & 218 & 339 & 36.3 \\
\hline 11 & 1.5 & 47 & 245 & 306 & 32 & 0.38 & 0.09 & 0.55 & 273 & 336 & 36 \\
\hline 12 & 1.8 & 64 & 290 & 420 & 32 & 0.43 & 0.1 & 0.6 & 319 & 453 & 35.8 \\
\hline 13 & 1.8 & 64 & 290 & 420 & 32 & 0.43 & 0.1 & 0.6 & 319 & 453 & 35.8 \\
\hline 14 & 1.5 & 62 & 220 & 310 & 31 & 0.36 & 0.03 & 0.55 & 246 & 341 & 35.3 \\
\hline 15 & 1.5 & 63 & 220 & 332 & 31 & 0.42 & 0.07 & 0.39 & 244 & 362 & 34,5 \\
\hline 16 & 1.5 & 79 & 240 & 325 & 30 & 0.5 & 0.05 & 0.53 & 262 & 358 & 34.4 \\
\hline 17 & 2.0 & 77 & 235 & 325 & 29 & 0.36 & 0.08 & 0.27 & 269 & 354 & 33.4 \\
\hline 18 & 1.8 & 59 & 255 & 340 & 29 & 0.48 & 0.11 & 0.43 & 284 & 372 & 33.3 \\
\hline 19 & 1.8 & 59 & 250 & 320 & 29 & 0.34 & 0.09 & 0.5 & 283 & 351 & 33.3 \\
\hline 20 & 2.0 & 77 & 245 & 330 & 27 & 0.53 & 0.07 & 0.51 & 273 & 359 & 30.8 \\
\hline 21 & 1.5 & 63 & 205 & 250 & 26 & 0.4 & 0.06 & 0.45 & 222 & 277 & 30.1 \\
\hline 22 & 2.0 & 77 & 273 & 345 & 24 & 0.53 & 0.06 & 0.45 & 303 & 373 & 28.4 \\
\hline 23 & 1.8 & 79 & 261 & 350 & 24 & 0.42 & 0.03 & 0.5 & 291 & 377 & 28.3 \\
\hline 24 & 1.8 & 79 & 270 & 350 & 24 & 0.35 & 0.1 & 0.47 & 308 & 383 & 27.8 \\
\hline 25 & 1.8 & 45 & 285 & 355 & 37 & 0.7 & 0.25 & 0.32 & 297 & 372 & 33.6 \\
\hline 26 & 1.8 & 59 & 285 & 355 & 36 & 0.34 & 0.09 & 0.5 & 284 & 372 & 33.3 \\
\hline 27 & 1.8 & 51 & 300 & 370 & 35 & 0.7 & 0.13 & 0.53 & 305 & 380 & 33.1 \\
\hline 28 & 1.5 & 63 & 300 & 370 & 36 & 0.6 & 0.14 & 0.04 & 331 & 407 & 32.6 \\
\hline 29 & 1.8 & 51 & 290 & 365 & 35 & 0.7 & 0.21 & 0.5 & 336 & 400 & 32.3 \\
\hline 30 & 1.5 & 63 & 295 & 370 & 36 & 0.7 & 0.22 & 0.49 & 325 & 416 & 31.9 \\
\hline 31 & 1.8 & 51 & 300 & 370 & 35 & 0.7 & 0.13 & 0.53 & 305 & 377 & 31.4 \\
\hline 32 & 1.8 & 64 & 290 & 365 & 36 & 0.6 & 0.17 & 0.54 & 318 & 382 & 31.2 \\
\hline 33 & 1.8 & 51 & 280 & 355 & 36 & 0.5 & 0.19 & 0.49 & 327 & 386 & 31.1 \\
\hline 34 & 2.0 & 77 & 295 & 370 & 36 & 0.6 & 0.15 & 0.02 & 333 & 400 & 30.9 \\
\hline 35 & 1.5 & 79 & 305 & 370 & 35 & 0.8 & 0.09 & 0.02 & 352 & 398 & 30.4 \\
\hline 36 & 1.5 & 79 & 305 & 370 & 35 & 0.8 & 0.09 & 0.02 & 319 & 392 & 30 \\
\hline 37 & 1.8 & 79 & 285 & 360 & 36 & 0.7 & 0.13 & 0.53 & 334 & 397 & 29.9 \\
\hline 38 & 1.8 & 79 & 300 & 370 & 35 & 0.6 & 0.17 & 0.37 & 347 & 380 & 29.9 \\
\hline 39 & 2.0 & 77 & 295 & 370 & 36 & 0.6 & 0.15 & 0.02 & 342 & 404 & 29.9 \\
\hline 40 & 2.0 & 77 & 290 & 365 & 36 & 0.7 & 0.09 & 0.02 & 342 & 396 & 29.3 \\
\hline 41 & 1.5 & 63 & 300 & 360 & 35 & 0.7 & 0.18 & 0.36 & 352 & 414 & 29.2 \\
\hline 42 & 1.8 & 45 & 290 & 365 & 36 & 0.6 & 0.24 & 0.55 & 299 & 382 & 29 \\
\hline 43 & 2.0 & 77 & 285 & 360 & 36 & 0.6 & 0.18 & 0.44 & 334 & 385 & 28.7 \\
\hline 44 & 1.5 & 63 & 295 & 345 & 36 & 0.7 & 0.18 & 0.36 & 316 & 395 & 26.6 \\
\hline 45 & 1.5 & 63 & 290 & 365 & 36 & 0.6 & 0.14 & 0.46 & 310 & 407 & 26 \\
\hline 46 & 1.5 & 49 & 305 & 370 & 35 & 0.6 & 0.14 & 0.04 & 304 & 391 & 25 \\
\hline 47 & 1.5 & 47 & 310 & 370 & 35 & 0.7 & 0.24 & 0.43 & 321 & 397 & 24.7 \\
\hline 48 & 1.5 & 47 & 295 & 360 & 36 & 0.9 & 0.19 & 0.59 & 357 & 401 & 23.2 \\
\hline
\end{tabular}




\subsection{Analysis of variance (ANOVA)}

Weight ratios of the included elements $(\mathrm{C}, \mathrm{Si}, \mathrm{Mn}, \mathrm{P}, \mathrm{S}$ and remaining elements) in the raw material, mechanical properties (yield strength, tensile strength and elongation) of the material before cold rolling process and the reduction rate were selected as independent parameters. However, by performing the variance analysis using a commercial statistical software package (DesignExpert 7.0.3), it was found that some of the independent input parameters are not influential and have no significant effect on the dependent parameters. Analysis of variance results are tabulated in Table II. Therefore, in constructing of the the gene expression programming (GEP) models only significant independent variables were used. The $F$ value in Table II provides an information of the degree of contribution of the independent parameters to the measured dependent parameter (test results). If the $F$ is high, the contribution of the factors to that particular response is high $[8,9]$. This analysis was carried out for a level of confidence of $90 \%$ i.e., for a level of significance of $10 \%$. Significant parameters on dependent variables according to the ANOVA are accentuated in Table II.

\subsection{Gene expression programming model}

Genetic expression programming was proposed by Koza as an extension to genetic algorithms to extract intelligible relationships in a system automatically [10]. Randomly generated general and hierarchical computer programs with tree structure varying in size and structure are created by GEP. Main goal of the GEP is to solve a problem by searching highly fit computer programs in the space of all possible solutions. Ranges of the dependent and independent parameters which were used in GEP modelling are given in Table III. Mathematical models of the dependent variables were developed using GEP with parameters listed in Table IV.

\section{Results and discussion}

\subsection{Evaluation of GEP models}

Table $\mathrm{V}$ presents statistical parameters of train and test sets of GEP formulations. R2, MSE and MAE correspond to the coefficient of correlation, mean square error and mean absolute error of proposed GEP model, respectively.

Following equations are obtained by utilisation of GEP:

$$
\begin{aligned}
& Y s_{f}=\left(2.52+Y s_{i}+\frac{R r}{2.52}\right), \\
& T s_{f}=0.14+2 T s_{i}+0.72 R r+T_{0}+\frac{90.04}{T_{0}^{2}}, \\
& E_{f}=6.33+\frac{T s_{i}}{E_{i}}+E_{i}(1-M n)+\frac{Y s_{i}^{2}}{T s_{i}\left(7.28 E_{i}\right)},
\end{aligned}
$$

where $Y s_{f}$ is final yield strength, $Y s_{i}$ is initial yield strength, $R r$ is reduction rate, $T s_{f}$ is final tensile strength, $E_{i}$ is initial elongation, $T s_{i}$ is initial tensile

\begin{tabular}{|c|c|c|c|}
\hline & Source of variance & $F$ value & $P$ value \\
\hline \multirow{11}{*}{$\begin{array}{c}\text { Yield } \\
\text { strength } \\
\text { of cold } \\
\text { rolled } \\
\text { product }\end{array}$} & A-T0 & 0.90 & 0.35 \\
\hline & B-reduction rate & 7.70 & 0.01 \\
\hline & C-yield 1 & 16.03 & $<0.01$ \\
\hline & D-tensile 1 & 0.50 & 0.48 \\
\hline & E-elongation & 0.09 & 0.77 \\
\hline & $\mathrm{F}-\mathrm{C}$ & 0.62 & 0.44 \\
\hline & G-Si & 0.05 & 0.82 \\
\hline & $\mathrm{H}-\mathrm{Mn}$ & 0.32 & 0.58 \\
\hline & J-P & 0.34 & 0.56 \\
\hline & $\mathrm{K}-\mathrm{S}$ & 0.92 & 0.34 \\
\hline & L-Alt & 0.42 & 0.52 \\
\hline \multirow{11}{*}{$\begin{array}{c}\text { Tensile } \\
\text { strength } \\
\text { of cold } \\
\text { rolled } \\
\text { product }\end{array}$} & A-T0 & 3.99 & 0.05 \\
\hline & B-reduction rate & 4.85 & 0.03 \\
\hline & C-yield 1 & 1.88 & 0.18 \\
\hline & D-tensile 1 & 136.30 & $<0.01$ \\
\hline & E-elongation & 1.04 & 0.31 \\
\hline & $\mathrm{F}-\mathrm{C}$ & 0.08 & 0.77 \\
\hline & G-Si & 0.85 & 0.36 \\
\hline & $\mathrm{H}-\mathrm{Mn}$ & 0.41 & 0.52 \\
\hline & J-P & 0.38 & 0.54 \\
\hline & $\mathrm{K}-\mathrm{S}$ & 1.36 & 0.25 \\
\hline & L-Alt & 0.89 & 0.35 \\
\hline \multirow{11}{*}{$\begin{array}{c}\text { Elongation } \\
\text { of cold } \\
\text { rolled } \\
\text { product }\end{array}$} & A-T0 & 0.54 & 0.47 \\
\hline & B-Reduction Rate & 0.00 & 0.97 \\
\hline & C-yield 1 & 6.13 & 0.02 \\
\hline & D-tensile 1 & 4.53 & 0.04 \\
\hline & E-Elongation & 45.19 & $<0.01$ \\
\hline & $\mathrm{F}-\mathrm{C}$ & 0.00 & 0.96 \\
\hline & $\mathrm{G}-\mathrm{Si}$ & 1.25 & 0.27 \\
\hline & H-Mn & 11.82 & $<0.01$ \\
\hline & $\mathrm{J}-\mathrm{P}$ & 0.16 & 0.69 \\
\hline & $\mathrm{K}-\mathrm{S}$ & 0.09 & 0.77 \\
\hline & L-Alt & 0.98 & 0.33 \\
\hline
\end{tabular}

TABLE II

ANOVA results.

TABLE III

Input and output variables used for GEP.

\begin{tabular}{c|c|c}
\hline \hline & Variable & Range \\
\hline Input & Initial reduction rate [\%] & $44.89-79.44$ \\
Input & Initial yield strength [MPa] & $205-310$ \\
Output & Final yield strength [MPa] & $218-357$ \\
Input & Initial sheet thickness [mm] & $1.5-2.0$ \\
Input & Reduction rate [\%] & $44.89-79.44$ \\
Input & Initial tensile strength [MPa] & $250-420$ \\
Output & Final tensile strength [MPa] & $277-453$ \\
Input & Initial yield strength [MPa] & $205-310$ \\
Input & Initial tensile strength [MPa] & $250-420$ \\
Input & Initial elongation [\%] & $23.8-37.6$ \\
Input & Weight ratio of Mn [\%] & $0.179-0.420$ \\
Output & Final elongation [\%] & $23.2-41.6$
\end{tabular}


TABLE IV

Parameters used for GEP model.

\begin{tabular}{l|c|c}
\hline \hline P1 & Function set & $+,-, *, /, \sqrt{ }$, exp, ln, \\
P2 & Number of genes & $1,2,3$, \\
P3 & Head size & $3,5,8$ \\
P4 & Linking function & Addition $(+)$, Multiplication $\left(^{*}\right)$ \\
P5 & Number of generation & 10000 and 20000 \\
P6 & Chromosomes & $30-45$ \\
P7 & Mutation rate & 0.044 \\
P8 & Inversion rate & 0.1 \\
P9 & One-point recombination rate & 0.3 \\
P10 & Two-point recombination rate & 0.1 \\
P11 & Gene recombination rate & 0.1 \\
P12 & Gene transposition rate & 0,1
\end{tabular}

TABLE V

Statistical parameters of GEP formulations.

\begin{tabular}{c|c|c|c|c|c|c}
\hline \hline & \multicolumn{2}{|c|}{ Final yield } & \multicolumn{2}{c|}{ Final tensile } & \multicolumn{2}{c}{ Final elongation } \\
\cline { 2 - 7 } & Training & Test & Training & Test & Training & Test \\
\hline MSE & 185.46 & 158.71 & 51.51 & 144.25 & 4.15 & 3.54 \\
MAE & 10.36 & 9.47 & 5.42 & 9.21 & 1.57 & 1.59 \\
$\mathrm{R}^{2}$ & 0.88 & 0.90 & 0.95 & 0.91 & 0.77 & 0.85
\end{tabular}

strength, $T_{0}$ is initial sheet thickness, $E_{f}$ is final elongation and $M n$ is weight ratio of manganese.

It should be noted that formulations above are valid for the ranges of training value sets for independent variables which are given in Table II. Evaluation of GEP models final mechanical properties for train and test data sets are presented in Fig. 1.
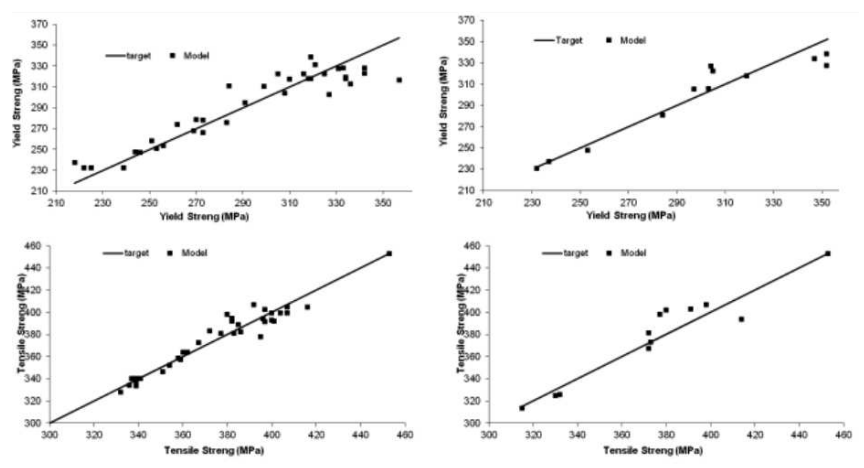

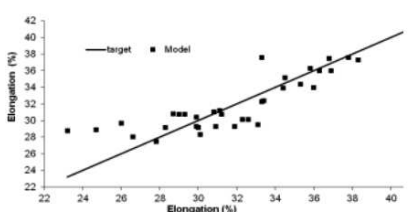

(a)

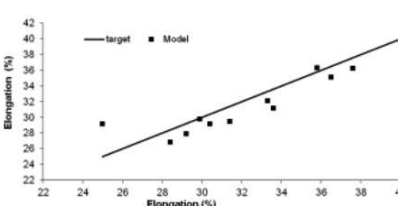

(b)
Fig. 1. Evaluation of GEP model for (a) training and (b) testing data sets.

\subsection{The effects of independent variables on final mechanical properties}

Effect of reduction rate on yield strength of final product with respect to initial yield strength based on GEP results is presented in Fig. 2. As it is seen in the figure, increasing the reduction rate increases the final yield strength gradually, increasing the initial yield strength also demonstrates the same effect. The slopes of the final yield strength vs reduction rate graphs for different initial yield strengths are exactly the same. Probably, this is because of the effect of grain refinement, which is increasing with reduction rate [3].

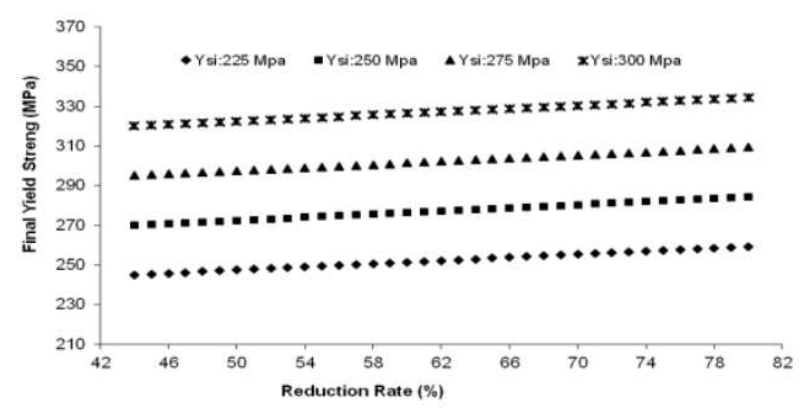

Fig. 2. Effect of reduction rate on yield strength of final product.
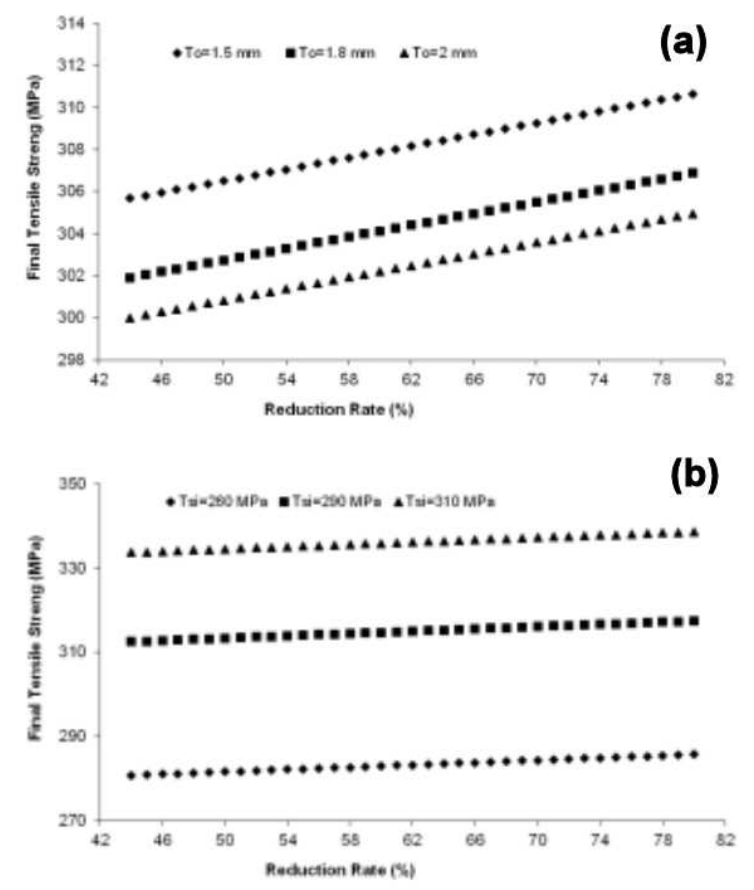

Fig. 3. Effect of reduction rate on final tensile strength with respect to (a) initial sheet thickness (b) initial tensile strength.

Figure 3a shows the effect of reduction rate on final tensile strength with respect to initial sheet thickness. From this figure final tensile strength increases with the increase of reduction rate. This must be a result of increase in the yield strength with reduction rate which is seen in Fig. 2. In addition, tensile strength of final product is slightly higher for thin sheets. For same reduction rate, it was found that the final thickness of cold formed sheet is small if its initial sheet thickness is small. Therefore annealing, which increases the toughness, is more effective for thin products. 
For the same initial tensile strength values, to increase the final tensile strength, reduction rate might be increased. It is known that increasing the reduction increases the final yield strength. However, as is demonstrated in Fig. 3b, increasing the reduction rate from 44 to $80 \%$ increases the final tensile strength by only about $3 \mathrm{MPa}$. It can be concluded from Fig. 3b that increasing of reduction rate has lessened the toughness marginally.

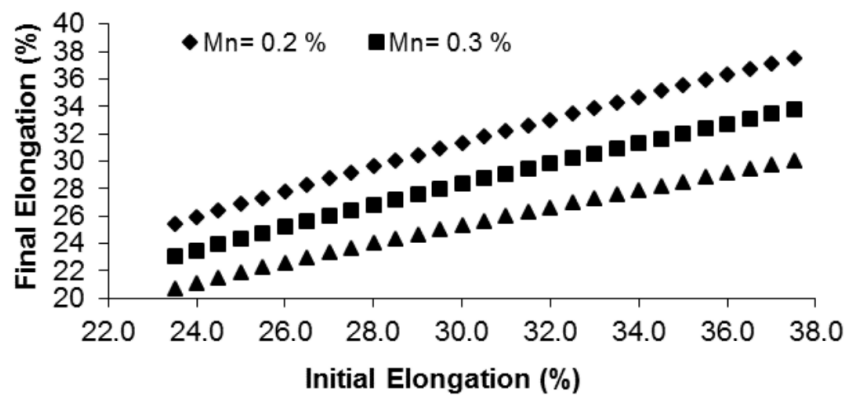

Fig. 4. Effect of Mn content on final elongation with respect to elongation before cold rolling.

Effect of Mn content on variation of elongation can be seen in Fig. 4. It can be concluded from the graph that increase in the Mn content decreases the ductility. Similarly final elongation rates are lower with respect to initial elongation values for material with higher initial yield strength as can be observed in Fig. 5 .
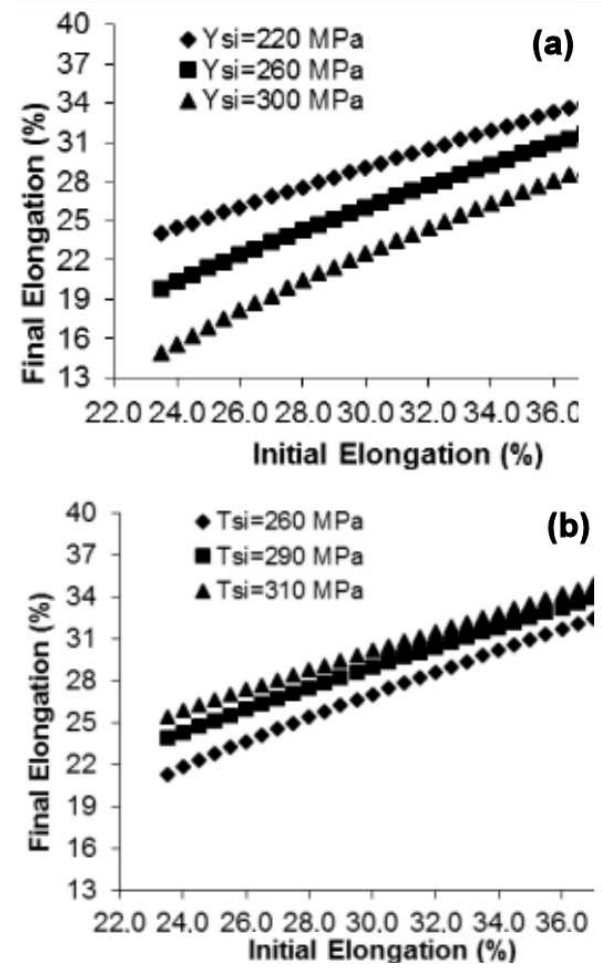

Fig. 5. Effect of Initial elongation on final elongation with respect to (a) initial yield strength (b) initial tensile strength.
Increase in initial tensile strength has a negative effect on final elongation of final product as seen in Fig. 5. This negative effect is more obvious for materials with lower initial elongation values.

\section{Conclusions}

Effects of chemical composition, mechanical properties, initial sheet thickness and reduction rates of cold rolled low carbon steel have been studied. First ANOVA has been used to determine significant independent parameters on the mechanical properties. Then a mathematical model between the statistically significant independent and dependent parameters was generated by GEP for the purpose of predicting final yield strength, final tensile strength and elongation of cold rolled and galvanized steel sheet. Following conclusions have been drawn from this study:

1. Yield strength of the raw material is the most significant parameter for yield strength of final product.

2. Reduction ratio of the cold rolling is second significant parameter for yield strength of final product.

3. Final tensile strength increases linearly with the increase of reduction rate. It is affected positively by the initial tensile strength and negatively by initial sheet thickness for same reduction rates.

4. Increase in the $\mathrm{Mn}$ content between $0.179 \%$ and $0.420 \%$ has a negative effect on elongation of the final product.

5. Initial tensile strength has a positive effect on final elongation value. On the other hand it decreases with increase in initial yield strength.

\section{References}

[1] G. Krauss, Steels: Processing, Structure, and Performance, ASM International, Ohio, USA 2005, p. 217.

[2] M. Durand-Charre, Microstructure of Steels and Cast Irons, Springer-Verlag, Berlin Heidelberg 2004, p. 253.

[3] F. Popa, I. Chicinaş, D. Frunză, I. Nicodim, D. Banabic, Int. J. Miner. Metal. Mater. 21, 273 (2014).

[4] J. Pero-Sanz, M. Ruiz-Delgado, V. Martinez, J.I. Verdeja, Mater. Charact. 43, 303 (1999).

[5] R.K. Ray, M.P. Butron-Guillen, J.J. Jonas, G.E. Ruddle, ISIJ Int. 32, 203 (1992).

[6] L.I. Zhuang, W.U. Di, L. Wei, J. Iron Steel Res. Int. 19, 64 (2012).

[7] A. Brahme, M. Winning, D. Raabe, Comput. Mater. Sci. 46, 800 (2009).

[8] A. Rutherford, Introducing Anova and Ancova: A GLM Approach, SAGE Publications, 2001, p. 15.

[9] M. Şahmaran, Z. Bilici, E. Ozbay, T.K. Erdem, H.E Yucel, M. Lachemi, Compos. Part B: Eng. 45 , 356 (2013).

[10] J.R. Koza, Genetic programming on the programming of computers by means of natural selection, MIT Press, London, England 1998. 